\title{
An Exploration of the Link between Minority Ethnic and White Students' Degree Attainment and Views of Their Future 'Possible Selves'
}

\author{
Jacqueline Stevenson \\ Correspondence: Jacqueline Stevenson, Centre for Social and Educational Research across the Lifecourse, Leeds \\ Metropolitan University, Headingley Campus, Leeds LS3 3QN, Fairfax 204, UK. E-mail: \\ j.stevenson@leedsmet.ac.uk
}

Received: October 20, 2012 Accepted: November 5, 2012 Online Published: November 28, 2012

doi:10.5539/hes.v2n4p103 URL: http://dx.doi.org/10.5539/hes.v2n4p103

\begin{abstract}
There is a significant gap in degree attainment between White and minority ethnic (ME) students in the UK as measured by the percentage awarded a 'good' degree. The causes for the gap are highly complex; however outcomes for ME students are lower than for their White peers across the whole of the UK higher education sector. This paper explores the extent to which students views of what they believe or expect they can become, their academic 'possible selves' (Markus and Nurius, 1986), may inform their academic help seeking strategies and their subsequent degree attainment. Drawing on group interviews with seventy full-time, undergraduate White and ME students studying at two UK 'Russell group' universities the research finds that a lack of congruence between hoped for, true and 'ought to' selves may be informing, and limiting, the academic help-seeking strategies of Black, Asian and Chinese students compared to their White peers.
\end{abstract}

Keywords: higher education, possible selves, minority students, degree attainment

\section{Introduction}

The percentage of UK-domiciled Minority Ethnic (ME) students studying in higher education (HE), at all levels, is statistically higher than that of White students (ECU, 2011). However, there is a significant gap in degree attainment between White and ME students. In the UK degree classifications are: First class honours $\left(1^{\text {st }}\right)$, Second class honours, upper division (2:i); Second class honours, lower division (2.ii); Third class honours ( $3^{\text {rd }}$ ) and Ordinary degree (Pass). Data shows that while $66.5 \%$ of White students studying first degrees receive a $1^{\text {st }}$ or 2.ii honours degree, widely known in the UK as a 'good degree', only $49.2 \%$ of ME students and $38.1 \%$ of Black students did so (ECU, 2011).

Research by both the former UK Department for Education and Skills (Broecke and Nicholls, 2007) and the Higher Education Funding Council for England (HEFCE, 2010) found that differences in the attainment between White and ME groups could only in some small part be explained by the differing profiles of the students (such as prior attainment, age, gender, disability, deprivation, type of HE institution attended). Even after controlling for the majority of contributory factors, being from a ME group was still found to have a statistically negative effect on degree attainment. Outcomes for ME students are lower than for their White peers across the whole of the UK HE sector, including within Russell Group universities, the leading 24 UK research-intensive universities including Oxford and Cambridge.

The reasons for the attainment gap are highly complex, and understanding and addressing higher educational disparities requires a recognition of the interplay of structural barriers, including poverty and racism, organizational barriers such as teaching and assessment practices and a lack of ME role models, and cultural barriers such as individual and institutional values and beliefs (Law et al., 2004; Richardson, 2008; Berry and Loke, 2011; Singh, 2011, Stevenson, 2012). Arising from, and as a consequence of these, are students' individual psychological factors, such as their academic confidence, expectation and motivation. Indeed there is a substantial body of literature relating to the impact of psychological factors on academic attainment in the UK for example, Sander's work on academic behavioural confidence (Sander, 2009; Sander and Sanders, 2009), as well as work on student engagement and belonging (Read et al., 2003; Reay et al., 2010 among others). However, little research has specifically focused on the individual psychological factors of ME students (exceptions being 
Pawson et al, 2012; Stuart, 2009). This is probably unsurprising since locating, even in part, the 'cause' of ME student underachievement within individuals themselves runs the danger of collapsing explanations for the attainment gap back in to a deficit model of blaming ME students for their academic 'failures'.

Recent research exploring the ME degree attainment gap in the UK (Stevenson, 2012), however, highlighted that many ME students had unclear views about how they might set about attaining a 'good' degree. In particular, there were stark differences between the academic approaches of students from different ethnic backgrounds, in both Russell Group and non-Russell Group institutions. These results were somewhat unexpected and provoked questions about whether ME students' views of what they believe or expect they can 'become', and the subsequent steps they put in place to achieve their goals, may affect their academic outcomes. In previous research I had drawn on the 'possible selves' literature (Markus and Nurius, 1986) in relation to the participation in extra-curricular activities of students from different socio-economic classes in UK HE (Stevenson, 2011). This research found marked variation between students both in terms of their orientation towards the future, as well whether or not they were participating in different forms of extra-curricular activities in order to achieve a desired future career and become the future employed. Whilst this particular research focused on students' gender and class backgrounds the results also suggested that the possible selves literature might be a useful heuristic for exploring ethnic differences in the ways in which students' think about their futures and the strategies they may or may not undertake to try and achieve them.

Whilst rarely drawn on in the UK there is an extensive body of research in North American and, to a lesser extent, in Canada drawing on the construct of the possible self. In an educational context, such research has been undertaken with ME high school adolescents, with ME students in highly diverse US colleges and universities, and/or with international students (see Pi-Ju Yang and Noels 2012 for a Canadian perspective). In the UK, however, there has been little research in HE institutions drawing on the possible selves literature (exceptions being Stevenson, 2011), with none undertaken at Russell Group universities, dominated by white, middle-class, affluent students. Indeed only limited research has explored the specific outcomes of students studying within Russell Group universities at all, with much of this being quantitative rather than qualitative (Fielding, 2008; Richardson, 2008). This is a significant omission since ME students are not only under-represented in Russell Group institutions (Business in the Community, 2010), but many feel isolated, unsupported and struggle to fit in once there (NUS, 2011). I was interested, therefore, in drawing on the possible selves literature in relation to degree attainment in the UK to explore whether ME students' views of what they believe or expect they can become may affect their academic outcomes.

In this paper, consequently, I begin by exploring the possible selves literature before going on to describe research undertaken at two Russell Group universities. I draw on data from eight group discussions with White and ME students, using insights from the possible selves literature to highlight similarities and differences between the students' hoped for, feared, and expected possible selves and how 'true' these appear to be and the level of congruence between their hoped for, true and 'ought to' selves. I then focus on the students' goal-focused academic help-seeking activities, drawing particular attention to ethnic differences. I conclude by exploring what ME and White students consider to be possible, the strategies they are putting in place to try and achieve their hoped-for future selves, and the possible link with their degree attainment outcomes.

\section{Theoretical Framework}

The Possible Selves theoretical framework was developed in the US by Hazel Markus and Paula Nurius (1986). Possible selves are an individual's cognitively-based, future-oriented aspect of one's self-concept, developed within specific socio-cultural contexts (Markus \& Nurius, 1986). Through personalized beliefs about the future-self individuals are able to project 'what they might become, what they would like to become, and what they are afraid of becoming' (Markus \& Nurius, 1986, p. 954). Possible selves may be experienced multiply or singly and may relate to one or to multiple views of a future career, education, health, lifestyle or social standing etc. (Horstmanshof \& Zimitat, 2003), for example, "the "clever" self who passed the algebra test, the "healthy" self who lost weight, the "drop-out" self who failed to graduate from high school, the "off-track" self who uses drugs or becomes pregnant' (Oyserman et al., 2007). Possible selves may also relate to generalized states (sad, happy or fulfilled) as well as specific roles (student, parent or lawyer); they may be highly developed or elaborated, or undeveloped, whilst some aspects of a desired possible self may also have more salience than another (Garcia and Pintrich, 1995; Vick, 2011).

The possible selves a person is able to envisage are, however, dependent on social, cultural, economic and historical backgrounds (Oyserman et al., 1995; Vick, 2011), and are drawn from 'the pool of possible selves...categories made salient by the individual's particular socio-cultural and historical context[s] and...by 
the individual's immediate social experiences' (Markus and Nurius, 1986, p. 954). Thus possible selves are also informed by gender (Chalk et al., 2005; Lips, 2002), class (Stevenson, 2011) and, increasingly, race (Oyserman, et al, 1995; Kao, 2000; Yowell, 2002; Oyserman, et al, 2004; Oyserman \& Fryberg, 2006 ; Frazier, 2009; Turcios-Cotto, 2011; Vick, 2011)

One of the most significant aspects of the concept of the possible self is that it provides a link between self-concept and motivation: individuals with an elaborated and developed view of their future self are more likely to strive to become their hoped-for selves, or avoid becoming their feared ones (Markus \& Ruvolo, 1989; Hock et al., 2006). In addition, individuals with elaborated views of their possible selves are more likely to develop goals and strategies in the pursuit of attaining them (Markus \& Nurius, 1986). Conceptions of possible selves, therefore, can be viewed as 'the cognitive manifestations of enduring goals, aspirations, motives, fears and threats' (Markus and Nurius (1986p. 954).

In the North American literature, there is an emerging body of schools-based research which has highlighted how academic possible selves can engender engagement in academic activities (Oyserman et al., 1995; Oyserman et al., 2004), persistence and motivation (Leondari et al., 1998; Oysermann \& Fryberg, 2006) and increase school involvement and grades (Oyserman et al., 2002). In addition, those students with feared possible selves are more likely to put in place goal-directed action in order to avoid them (Yowell, 2002). Pi-Ju Yang and Noels' (2012) research exploring relations between international students' possible selves and cultural adjustment in Canada, for example, evidences how elaborated possible selves relating to career, education and interpersonal domains can help with students' psychological well-being and intercultural adjustment.

However, as Oyserman et al. (2004) have identified, without proper planning and the focused direction of adopted strategies, desired outcomes may not be either achieved or avoided. Possible selves are, therefore, also contingent on whether they are validated and affirmed, or threatened or ignored, by those around the individual (Markus, 2006) including, in particular, family (Pizzolato, 2006; Pizzolato \& Slatton, 2007) and teachers (Oyserman et al., 2002; Yowell, 2002; Frazier, 2009). Research by Kao (2000) amongst others has linked differing academic attainment to ways in which the possible selves of different ethnic groups of students are constrained or affirmed by those close to the individual. Kao found that not only did the adolescents in her research 'define their goals primarily in terms of the stereotypical images attached to their ethnic group' (p. 407) (such as high achieving Asians) but their views of what self was possible was reinforced by the expectations of their teachers (such as Asians being academically gifted).

In addition, actual or 'true' possible selves may contradict other important social identities (Osyerman et al, 2006) such as 'fitting in' and belonging to a particular social or ethnic group. Consequently the 'hoped for' future that an individual might describe may not therefore be their 'true' self. Higgins (1987) also makes an important distinction between (three) different selves: the 'actual self' (how the individual or those around them believe they actually are), the 'ideal self' (how the individual would like to see themselves, including their 'hoped for' possible selves) and the 'ought to self' (the attributes the individual believes they should possess). These different selves may not be in congruence with each other. Focussing on academic help-seeking strategies and the relationship between students and academic staff is important in exploring degree attainment therefore, since the desire to achieve a particular 'academic' possible self alone is insufficient unless it is linked with plausible strategies, and, in particular, made to feel like a 'true' self (Oyserman et al. 2006) and there is congruence with the 'ought to' self.

\section{Method}

The key questions for this research were, therefore:

- How, if at all, do students' views of their academic and career possible selves differ by ethnic group, and how 'true' are these selves?

- What differences are there, if at all, in terms of how students conceptualise the possibilities and threats to achieving their hoped for possible selves?

- What academic help-seeking strategies are students undertaking to enable them to attain their hoped for, or avoid their feared, possible selves, and do these vary by ethnic group?

- Is there a relationship between students' imagined academic possible selves into the future and their goal focused action in the present?

The research was undertaken via a series of eight group discussions comprising 70 'home/EU', full-time, undergraduate students from diverse ME and white backgrounds, studying at two Russell group universities with similar sized student bodies and numbers of ME students. The students were recruited by the Students Unions of 
the two universities using a systematic sampling strategy drawing on ethnic data from the respective institutional databases. Since one of the purposes of the study was to explore whether there were different possible selves and actions between groups of students from different ethnic backgrounds, the students were deliberately recruited into ethnic-specific groups: Black, Asian (Note 1), White and Chinese. Russell Group University 2 was unable to recruit a Chinese cohort so a mixed-ethnicity group discussion was run, with individual students' comments aligned to their ethnic peers from the other group discussions (see Table 1). The overall cohort comprised 41 women and 29 men of whom only two were over 25 and thus might be classed as 'mature'. The rest were aged $18-23 ; 22$ of the students were in their first year, 24 in their second, 18 in their third and 6 students were in their fourth year of a four-year undergraduate degree. The students were also asked whether one or both parents had been to university, of whom 30 were 'first generation' (i.e. neither parent having studied at HE level). It is important to note that first-generation is by no means an absolute proxy for 'working-class'. However, previous parental education has a significant impact on achievement, aspiration, access to information and integration into UK HE (Stevenson, 2010), and has therefore been included in order to contextualise the students' responses. Additional demographic data was collated for each student relating to course, religion, whether state or privately educated, part time working (paid or voluntary), and caring responsibilities but for reason of simplicity only ethnicity, gender, age, year of study and whether $1^{\text {st }}$ or $2^{\text {nd }}$ generation is reported on when using students' quotes.

Table 1. Student demographics

\begin{tabular}{ccccc}
\hline & Asian & Black & White & Chinese \\
\hline Men & 9 & 8 & 7 & 5 \\
Women & 10 & 11 & 13 & 7 \\
\hline
\end{tabular}

The students were asked to describe the level of degree they were aiming for and their immediate post-graduate plans, the academic and other strategies they were putting in place to achieve their desired outcomes, as well the barriers which, they believe, might prevent them from attaining their desired possible selves. The group discussions were recorded, fully transcribed, and analysed using Nvivo ${ }^{\circledR}$ to draw out themes and areas of commonality and difference.

Through repeated reading of the transcripts I explored the different academic and career possible selves (hoped for, expected, feared, 'ought to') that the ME and White students describe, as well as how elaborated or 'true' these are; the threats that the students identify as being significant in enabling them to attain or avoid their possible selves; the actions they are undertaking to achieve their desired future possible selves, including their academic 'help-seeking' strategies; and the possible link between hoped for academic possible selves and goal focused actions across different ethnic groups.

The students in each of the group discussions were highly individual in their responses, and there were dissenting voices. In addition, there was a clear intersectionality with both class and gender which cannot be ignored. However, there were also strong themes and narratives across each of the different ethnic groups. What is described below, therefore, is the majority 'voice' of each cohort of students.

\section{Results}

\subsection{Hoped for, Feared, and 'True' Possible Selves}

Many of the students, especially those in their $3^{\text {rd }}$ and $4^{\text {th }}$ years and, in particular, the White students, had clearly elaborated notions of hoped for career possible selves either in a professional capacity (such as becoming a doctor), in research or academia, or working for a large, multinational organisation. The students were highly aware, due to media reporting, that there are over 80 graduates applying for every UK graduate job (AGR, 2011), with the vast majority of employers demanding that applicants have a minimum of a 2:1 (BBC, 2010; The Guardian, 2012). It is unsurprising, therefore, that all students who participated in the group discussions, regardless of ethnicity or year of study, stated that were aiming for a $1^{\text {st }}$ or a 2:i, believing this to be the minimum requirement for a 'good' job in their fields or for accessing post-graduate courses in the future. None of the students believed that they could become their hoped for possible self if they attained anything less than a 2:i:

'A First would be nice, a 2:i would be fine, a 2:ii would be catastrophic because it would just kill a lot of opportunities very quickly if I came out with a 2:ii so I'm hoping for a 2:i' (Tristan, White, Male, 21-23, 1st generation, 2nd year). 
Gaining a 'poor' degree was, for all of these students, a feared possible self and thus one to be avoided since, as one student stated 'If I come out with like a lower degree it's almost like I've just wasted 3/4 years in uni like' (Mary, Chinese, Female, 18-20, 1st generation, 2nd year).

Further probing, however, revealed that some students, particularly the Black students, were doubtful that they could in fact achieve so highly. Clearly all the Black students were high achievers, otherwise they would not have been accepted into a Russell Group university. However, some of them, the male students in particular, appeared to have internalised the negative stereotypes associated with their ethnic group, of failure, underperformance and 'bad' behaviour (BBC, 2008; Gosai, 2009), and consequently were 'performing race' (Willie, 2003). These Black, male students persistently described themselves as 'lazy' or 'un-academic', and as having 'poor attitudes' or 'poor time management':

'I can get a first class, but I just, I can't, I can't manage my time to get a first class. I'm, I'm lazy in that way, yeah. I mean, I can get a 2:1 though, it's just all the time-management' (Mohammed, Black, Male, 21-23, $1^{\text {st }}$ generation, $3^{\text {rd }}$ year).

'Like I've already said I'm not really that academic ... rather go out and see the world or something ... It's funny that you can be doing like chemical engineering and not be academic but it's just the way it goes'(Marcus, Black, Male, $18-20,2^{\text {nd }}$ generation, $1^{\text {st }}$ year).

The Black, male students not only described themselves in very negative ways, raising the possibility of their under-attainment becoming a self-fulfilling prophecy, but they also behaved in ways that had the potential to undermine their academic successes, particularly their desire not to stand out or be noticed in front of their peers. Consequently they rarely asked questions in lectures or spoke to their lecturers. As Lennie explains:

'If you speak to the lecturers, then like, when they see you, like, in lectures, they try and ask you questions, I don't really like, wanna be like pushed out into the crowd, I just wanna blend in. I'd rather they just did it and no one know. Go and do my business, and then leave after... I just don't use lecturers' (Lennie, Black, Male, 21-23, $1^{\text {st }}$ generation, $2^{\text {nd }}$ year).

For students such as Mohammed, Marcus and Lennie, therefore, their 'hoped for' selves (to achieve high academic results) were competing with their 'ought to' selves (to not over-perform and to not stand out academically).

In contrast, Asian students are often termed the 'model minority' in both the UK and North America because they exemplify high formal educational achievement leading to high levels of pressure on these students to perform well (BBC, 2008). It is perhaps unsurprising therefore that the Asian students in this study who were under-achieving blamed themselves, in part, for their own academic lack of success. In the case of both the male and the female Asian students they made sense of their apparent 'failures' by blaming themselves for a lack of academic knowledge and abilities:

'I've got like an incredibly short attention span...I end up losing my temper with it a bit and thinking like 'oh, I'll do better on the next one then, and I'll do better on the next one' and then by your last one you've done **** anyway...I find that I do so much research on something and I don't know how to explain it really cos I look stupid'(Layla, Asian, Female, 18-20, $2^{\text {nd }}$ generation, $3^{\text {rd }}$ year).

'Sometimes I think 'oh we've already covered it' and then they'll kind of like blame you. Sometimes they might help, they'd be like 'well that's already in the notes so you should go and find that out for yourself' (Ushma, Asian, Female, $18-20,2^{\text {nd }}$ generation, $1^{\text {st }}$ year).

The Asian students, therefore, whilst hoping to achieve academically, questioned whether they had the requisite knowledge and capabilities to be able to do so, indicating a lack of congruence between their hoped for and 'true' selves. These feelings of academic inadequacy and of not knowing enough made many of the students, particularly the female Asian students, cautious about asking their lecturers for help:

'As a final resort ask the lecturer...It's not because they're not friendly, a lot of them are and they're quite approachable, some of them, I don't know, it's just a bit awkward and sometimes like if you don't know it and they've already covered it in a lecture then you know that's your fault' (Sapna, Asian, Female, 21-23, $2^{\text {nd }}$ generation, $3^{\text {rd }}$ year).

However, both the Asian students and the Chinese students also strongly blamed the lecturers for threatening the achievement of their hoped for possible selves through poor academic practices, excused by senior managers, as Mary explains:

'It's an excuse sometimes like there's been complaints about like certain lecturers, the feedback is always they're 
really good, they're really good researchers, well, like, they're not good lecturers, like, and that's what they're there to do, aren't they, so like it's their excuse but it's not good enough really, if they're supposed to be teaching' (Mary, Chinese, Female, $18-20,1^{\text {st }}$ generation, $2^{\text {nd }}$ year).

Female Chinese students like Mary also commented extensively about the 'lack of care' demonstrated by the lecturers towards them which, they believed, also threatened the attainment of their hoped for possible selves. These students were particularly frustrated that they were left to 'cope' by themselves when struggling academically:

'I get the feeling like some of the lecturers just don't care, d'you know what I mean, especially like the PhD ones just have to do, have to do a module or whatever, but the ones who do care are like really helpful and, erm, they don't just like read the lecture notes out, but they try to teach you so, erm, yeah, if they could care a little more that would be helpful' (Jiao, Chinese, Female, 21-23, $2^{\text {nd }}$ generation, $2^{\text {nd }}$ year).

For both the Asian and the Chinese students there was, therefore, a disconnect between their hoped for future selves (to be high achievers), their 'true' selves (as lacking know-how, or being neglected, and therefore likely to under-perform) and their 'ought to' selves (to be seen by others as being high achievers).

The White students, in contrast, had a much greater congruence between their hoped for, true and 'ought to' selves, possibly because they possessed a strong belief (at times even an over-inflated belief) in their academic abilities. As Deborah, for example, commented when critiquing the feedback she received for an essay:

'It's very generic. It's vague, it's not constructive and the marking criteria I mean for example I put some very good ideas in my essay and they just didn't take them into account' (Deborah, White, Female, 21-23, $2^{\text {nd }}$ generation, $1^{\text {st }}$ year).

It is also clear that the White students rarely considered that there might be anything 'lacking' - either attitudinally or related to their academic skills - which might be either incongruent with, or pose a threat to the realisation of, their hoped for possible selves. Of all the students, the White students had the greatest confidence in their academic abilities and that they could, therefore, be academically successful. These students also appear to have internalised notions of their entitlement to be in UK higher education (Reay et al., 2005; Crozier et al, 2008) and more than any other group, regarded themselves as 'customers' of the university. Much of their criticism, therefore, centred on receiving an unsatisfactory 'service' despite paying for it. The White students, therefore, were also highly critical of the academic 'poor practices' which might prevent them from achieving their 'true' academic selves, such as lack of exam preparation, 'inadequate' feedback and 'inappropriate' support. They were, not unsurprisingly however, also willing to express their dissatisfaction and demand redress:

I've got a personal tutor and the one I've got now which I really don't like the one I've got now but it's too late to change so I had an issue with him like the other week and I emailed him to tell him that I didn't like the way that he'd handled something and then I saw him yesterday and he apologised 'cos he realised what he'd done was wrong'(Lauren, White, Female, 18-20, $1^{\text {st }}$ generation, $1^{\text {st }}$ year).

'I've been trying to contact a lecturer this week, I sent him one email last Wednesday and got no reply, sent him a slightly ruder one on Monday and he replied to me Monday night saying 'I can see you tomorrow morning" (Simon, White, Male, 18-20, $2^{\text {nd }}$ generation, $2^{\text {nd }}$ year).

\subsection{The Relationship between Academic Possible Selves and Goal Focused Actions in the Present}

Possible selves can create the link between hopes and current action by connecting present behaviors with future desired selves (Lee and Oyserman, 2007) giving them form, meaning, and direction (Markus and Nurius, 1986). However, to regulate behavior positive academic possible selves need to be linked not only to goals or desired end states but also to strategies to attain them (Oyserman et al., 2004; Oyserman et al., 2006). This can provide individuals with a 'road map' connecting the present to the future (Oyserman et al., 2004).

In response to their desire to be high achievers all the students interviewed for this research had adopted a range of academic help-seeking strategies. It is notable, however, that whilst there were some similarities across all four ethnic groups (such as undertaking independent reading, peer group study/consultations, and the use of online communities) there were also many differences between their 'road maps'.

The White students were the most strategic and purposeful in their academic help-seeking approaches and most likely to draw on all forms of support, including from their lecturers. They rarely avoided lectures and, more importantly, when they didn't understand something, unlike the Black, Chinese or Asian students, they would confront their lecturers for clarification. As Emily explains:

'I would just walk into their office to see them because they're all in the same building and you can just get their 
office number and I'd quite happily drop by if I needed any help... They seem grateful though when you go to them and they say 'where do you think you've got this equation from?' because it means that they've not explained it to the class well enough' (Emily, White, Female, 21-23, $1^{\text {st }}$ generation, $3^{\text {rd }}$ year).

Possible selves are rooted in past successes and failures (Lee and Oyserman, 2007) including experiences of success or failure in school and how individuals have historically been treated by those around them. The White students' sense of confidence in approaching lecturing staff may arise in part from the fact that they do not see any power asymmetries between themselves and their lecturers, nor do they feel they are likely to face any hostility if they challenge their lecturing practices. This appears to connect to the White students' feelings of entitlement to be in higher education, particularly in Russell Group institutions which have been, and still are, predominantly White. The Black and Asian students' reluctance to consult lecturers, in contrast, appears to be an acquired habit (possibly begun in school) of being self-reliant, consulting only with those 'the same as them', avoiding being seen as 'academic' and/or previous experiences of being rebuffed when asking for help:

'I don't know, maybe because I just relate better with PhD students because they've just, they've just been through the same thing, so, but with lecturers it's like, I don't know, it's like they are really high up there' (Annie, Black, Female, 21-23, $1^{\text {st }}$ generation, $4^{\text {th }}$ year).

'....And he's completely unhelpful anyway when you try and approach him outside of class. Because I've had some friends who've gone up to him and asked him just for further clarification and he's just plainly, he's just turned them away, said 'just stop wasting my time'so it's not really helpful at all' (Gurnam, Asian, Male, 24-26, $1^{\text {st }}$ generation, $2^{\text {nd }}$ year).

It is important to note, however, that none of the non-White students commented that they were being racially discriminated against or being treated in a racially discriminatory manner. Nonetheless, unlike the White students, many of the Black, Asian and Chinese students had devised specific coping strategies to ensure that meeting with their lecturers was regarded as unnecessary. Marcus, for example, who described himself as both lazy and un-academic, spoke of drawing on other students to gain 'expert' knowledge from the lecturers, whilst continuing to act out his race by not appearing to ask questions or appear 'academic':

'I'm a bit lazy about that [consulting lecturers] as well. Like all it takes is an email and cos me and Mel do the same course, she does the consulting' (Marcus, Black, Male, 18-20, $2^{\text {nd }}$ generation, $1^{\text {st }}$ year).

Gaynor, who also described herself as 'not being particularly clever' was also drawing on alternative, multiple academic help-seeking strategies, to enable her to avoid talking to lecturers, including consulting with her student peers:

'I do not consult lecturers that much, really. If I don't understand things, I just go to the book, or we also have a good online community in our year, so, er, as well as Blackboard, we have our own like club on Facebook and our own biomeds like groups, so if you don't understand things you have students who maybe have really researched it and they explain it to you, and because it's peer, you sort of understand it easier' (Gaynor, Black, Female, 21-23, $2^{\text {nd }}$ generation, $2^{\text {nd }}$ year)

However, the White students were also drawing on these multiple strategies as well as spending significant time talking to and working with their lecturers. Consequently the White students appeared to be placing themselves in a more advantageous academic position than their non-White peers.

\section{Discussion}

Whilst all the students interviewed for this research were aiming for high levels of academic attainment and feared attaining anything less than a $1^{\text {st }}$ or $2:$ i, different groups of students had developed, or were avoiding, different academic strategies to help them attain their hoped for selves. However, as Oyserman et al. (2004) argue 'self-regulation requires having action plans or strategies connected to self-relevant goals' (p. 145). The apparent lack of congruence between the hoped for and the true selves of many of the students appear to be informing, and limiting, their academic help-seeking strategies. For the Black male and the Asian and Chinese female students, in particular, there was also a lack of congruence between their hoped for and true possible selves and their views of what their 'ought to' selves should look like, causing them to further avoid specific academic help-seeking strategies.

The White students, in contrast, had a significantly greater congruence between their hoped for and true possible selves than their non-White peers, which appeared to be informing their academic help-seeking strategies, most specifically their relationships with their lecturers. By drawing on the skills and knowledge of their lecturers in the present these students may be more likely to attain their academic future possible selves in the future. 
The numbers of students who participated in this research were small. There were also significant variables in terms of gender, religion, disciplinary area, level of study, parental experience of HE, and whether state or privately educated. Nonetheless the research has indicated that there appear to be differences by ethnic group in terms of how true the students' possible selves are, how they conceptualise the possibilities and threats to achieving their hoped for possible selves, the academic help-seeking strategies they are undertaking to attain their hoped for possible selves, and the possible link between students' imagined academic possible selves, their goal focused actions in the present and their subsequent degree attainment.

To date little attention has specifically been given to the degree attainment gap - as it is understood in the UK - in either Canada or the United States. However, there is manifest evidence that minority ethnic students have lower levels of educational attainment than their white peers across both countries (United States Census Bureau, 2011; Frenette, 2011) and that, in the US, minority students in higher education achieve significantly lower grades than white students (Roth and Bobko, 2000; Massey, 2006; McKinney, 2009). In addition, in the UK, the attainment gap persists across all types of higher education institutions, not just the Russell Group universities (Stevenson, 2012). Further research drawing on the possible selves literature in other local and global higher education contexts is, therefore, important in order to ascertain whether the findings from this research have broader applicability.

\section{Acknowledgements}

Sincere thanks go to Dr Paula Sealey and Dr Milton Obamba for their help with this research.

\section{References}

Association of Graduate Recruiters (AGR). (2011). Figures show increase in graduate vacancies and boost in starting salaries for first time in 2 years. AGR website. Retrieved from http://www.agr.org.uk/Content/Figures-show-increase-in-graduate-vacancies-and-boost-in-starting-salariesfor-first-time-in-2-years

BBC. (2008). 'Stereotype' fear from race data. BBC website, 25 November 2008. Retrieved from http://news.bbc.co.uk/1/hi/education/7746004.stm

BBC. (2010). Three quarters of employers require 2:1 degree'. BBC online, 6 July 2012. Retrieved from http://www.bbc.co.uk/news/10506798

Berry, J., \& Loke, G. (2011). Improving the degree attainment of Black and minority ethnic students. London: ECU/HEA.

Business in the Community. (2010). Race into higher education. Today's diverse generation into tomorrow's workforce. London: Business in the Community.

Broecke, S., \& Nicholls, T. (2007). Ethnicity and Degree Attainment, DfeS Research Report RW92. London: DfES.

Chalk, L. M., Meara, N. M., Day, J. D., \& Davis, K. L. (2005). Occupational possible selves: Fears and aspirations of college women. Journal of Career Assessment, 13(2), 188-203. http://dx.doi.org/10.1177/1069072704273127

Crozier, G., Reay, D., Clayton, J., Colliander, L., \& Grinstead, J. (2008). Different strokes for different folks: Diverse students in diverse institutions - experiences of higher education. Research Papers in Education, 23(2), 167-177. http://dx.doi.org/10.1080/02671520802048703

Equality Challenge Unit (ECU). (2011). Equality in higher education: Statistical report 2011. London: ECU.

Fielding, A. (2008). Degree attainment, ethnicity and gender: Interactions and the modification of effects: A quantitative analysis, ECU/HEA. Retrieved from http://www.heacademy.ac.uk/assets/documents/research/EDA_Quantitative_Report_March08.pdf

Frazier, A. D. (2009). Academic Self-Concept and Possible Selves of high-ability African American males attending a specialized school for Gifted and Talented High School Students (Doctorial dissertation). Ball State University, Muncie, Indiana.

Frenette, M. (2011). What Explains the Educational Attainment Gap between Aboriginal and Non-Aboriginal Youth?, Canadian Labour Market and Skills Researcher Network Working Paper No. 78, Social Research and Demonstration Corporation. Retrieved from http://www.clsrn.econ.ubc.ca/workingpapers/CLSRN\%20Working\%20Paper\%20no.\%2078\%20-\%20Frenet te.pdf 
Garcia, T., \& Pintrich, P. R. (1995, April). The role of possible selves in adolescents' perceived competence and self-regulation. Paper presented at the meeting of the American Educational Research Association, San Francisco, California.

Gosai, N. (2009). Perspectives on the Educational Experiences of African/Caribbean Boys. A thesis submitted to The University of Birmingham for the degree of Doctor of Philosophy in Education. School of Education, The University of Birmingham, April 2009. Retrieved from http://etheses.bham.ac.uk/425/1/Gosai09PhD_A1a.pdf

Higher Education Funding Council for England (HEFCE). (2010). Student ethnicity: Profile and progression of entrants to full-time, first degree study. Retrieved from http://www.hefce.ac.uk/pubs/year/2010/201013/

Higgins, E. T. (1987). Self-discrepancy: A theory relating self and affect. Psychological Review, 94, 319-340. http://dx.doi.org/10.1037/0033-295X.94.3.319

Hock, M. F., Deshler, D. D., \& Schumaker, J. B. (2006). Enhancing student motivation through the pursuit of possible selves. In C. Dunkel \& J. Kerpelman (Eds.), Possible selves: Theory, research and applications (pp. 1-15). New York: Nova Science Publishers.

Horstmanshof, L., \& Zimitat, C. (2003). The elaboration of the student self and persistence in higher education. Paper presented at the New Zealand Association for Research in Education (NZARE)/Australian Association for Research in Education Conference, Auckland, New Zealand, 29 November-3 December 2003.

Kao, G. (2000). Group images and possible selves among adolescents: Linking stereotypes to expectations by race and ethnicity. Sociological Forum, 15(3), 407-430.

Law, I., Philips, D., \& Turney, L. (2004). Institutional Racism in Higher Education. Stoke on Trent: Trentham Books.

Lee, S. J., \& Oyserman, D. (2007). Reaching for the Future: The Education-Focused Possible Selves of Low-Income Mothers. New Directions for Adult and Continuing Education, 2007(114), 39-49. http://dx.doi.org/10.1002/ace.255

Leondari, A., Syngollitou, E., \& Kiosseoglou, G. (1998). Academic achievement, motivation and future selves. Educational Studies, 24(2), 153-163. http://dx.doi.org/10.1080/02673843.1998.9747820

Lips, H. M. (2002). Envisioning positions of leadership: The expectations of university students in Virginia and Puerto Rico. Journal of Social Issues, 57(4), 799- 13. http://dx.doi.org/10.1111/0022-4537.00242

Markus, H. (2006). Foreword. In C. Dunkel \& J. Kerpelman (Eds.), Possible selves: Theory, research and application. New York: Nova Science Publishers.

Markus, H., \& Ruvolo, A. (1989). Possible selves: Personalized representations of goals. In L. A. Pervin (Ed.), Goal concepts in personality and social psychology. Hillsdale, NJ: Erlbaum.

Markus, H., \& Nurius, P. (1986). Possible selves. American Psychologist, 41(9), 954-969. http://dx.doi.org/10.1037/0003-066X.41.9.954

Massey, D. S. (2006). Social Background and Academic Performance Differentials: White and Minority Students at Selective Colleges. American Law and Economic Review, 8, 390-409. http://dx.doi.org/10.1093/aler/ahl005

McKinney, A. P. (2009). Race-Based Differences in Performance Measures: Implications for Diversity Management in Higher Education and the Workforce. Journal of Diversity Management, 4(4), 23-30.

National Union of Students. (2011). Race for equality. A report on the experiences of Black students in further and higher education. London: NUS.

Oyserman, D., Brickman, D., \& Rhodes, D. (2007). School Success, Possible Selves, and Parent School Involvement. Family Relations, 56, 479-489. http://dx.doi.org/10.1111/j.1741-3729.2007.00475.x

Oyserman, D., Bybee, D., \& Terry, K. (2006). Possible selves and academic outcomes: How and when possible selves impel action. Journal of Personality and Social Psychology, 91(1), 188-204. http://dx.doi.org/ 10.1037/0022-3514.91.1.188

Oyserman, D., Bybee, D., Terry, K., \& Hart-Johnson, T. (2004). Possible selves as roadmaps. Journal of Research in Personality, 38, 130-149. http://dx.doi.org/10.1016/S0092-6566(03)00057-6

Oyserman, D., Gant, L., \& Ager, J. (1995). A socially contextualized model for African American identity: 
Possible selves and school persistence. Journal of Personality and Social Psychology, 69(6), 1216-1232. 156. http://dx.doi.org/10.1037/0022-3514.69.6.1216

Oyserman, D., Terry, K., \& Bybee, D. (2002). A possible selves intervention to enhance school involvement. Journal of Adolescence, 25, 313-326. http://dx.doi.org/10.1006/jado.2002.0474

Oyserman, D., \& Fryberg, S. (2006). The possible selves of diverse adolescents: Content and function across gender, race and national origin. In C. Dunkel \& J. Kerpelman (Eds.), Possible selves: Theory, research and application. New York: Nova Science Publishers.

Pawson, C., Randhawa, H., \& Harper, K. (2012). Exploring the Ethnic Divide in Degree Attainment: The Role of Academic Behavioural Confidence. Paper presented at the British Psychological Society Annual Conference 2012, London, U.K.

Pizzolato, J. E. (2006). Achieving college student possible selves: Navigating the space between commitment and achievement of long-term identity goals. Cultural Diversity and Ethnic Minority Psychology, 12(1), 57-69. http://dx.doi.org/10.1037/1099-9809.12.1.57

Pizzolato, J. E., \& Slatton, Z. L. (2007). The function of family involvement in adolescents' aspiration achievement. In P. R. Zelik (Ed.), Issues in the psychology of motivation. New York: Nova Science Publishers.

Read, B., Archer, L., \& Leathwood, C. (2003). Challenging Cultures? Student Conceptions of 'Belonging' and 'Isolation' at a Post-1992 University. Studies in Higher Education, 28(3), 261-277. http://dx.doi.org/10.1080/03075070309290

Reay, D., Crozier, G., \& Clayton, J. (2010). 'Fitting in' or 'standing out': Working-class students in UK higher education. British Educational Research Journal, 36(1), 107-124. http://dx.doi.org/10.1080/01411920902878925

Reay, D., David, M., \& Ball, S. (2005). Degrees of choice: Social class, race and gender in higher education. Stoke-on-Trent: Trentham Books.

Richardson, J. T. E. (2008). Degree attainment, ethnicity and gender: A literature review, ECU/HEA. Retrieved from http://www.heacademy.ac.uk/assets/documents/research/J_Richardson_literature_review_Jan08.pdf

Roth, P. L., \& Bobko, P. (2000). College grade point average as a personnel selection device: Ethnic group differences and adverse impact. Journal of Applied Psychology, 85, 399-406. http://dx.doi.org/10.1037//0021-9010.85.3.399

Sander, P. (2009). Current Developments in Measuring Academic Behavioural Confidence. Psychology Teaching Review, 15(1), 32-44.

Sander, P., \& Sanders, L. (2009). Measuring Academic Behavioural Confidence: The ABC Scale Revisited. Studies in Higher Education, 34(1), 19-35. http://dx.doi.org/10.1080/03075070802457058

Singh, G. (2011). Black and minority ethnic (ME) students' participation in higher education: Improving retention and success. A synthesis of research evidence. York: HEA.

Stevenson, J., \& Clegg, S. (2011). Possible selves: Students orientating themselves towards the future through extracurricular activity. British Educational Research Journal, 37(2), 231-246. http://dx.doi.org/10.1080/01411920903540672

Stevenson, J. (2012). Black and Minority Ethnic Student Degree Retention and Attainment. York: Higher Education Academy.

Stuart, M. (2009). The Impact of Social Identity and Cultural Capital on Different Ethnic Student Groups at University: Full Research Report. ESRC End of Award Report, RES-000-22-248. Swindon: ESRC.

Turcios-Cotto, V. Y. (2011). Racial/Ethnic Differences in Possible Selves of Diverse Adolescents: Implications for Higher Education and Mental Health (Master's Theses, Paper 200). Retrieved from http://digitalcommons.uconn.edu/gs_theses/200/

United States Census Bureau. (2011). Educational Attainment in the United States: 2011 - Detailed Tables. Retrieved from http://www.census.gov/hhes/socdemo/education/data/cps/2011/tables.html

Vasagar, J. (2012, July 4). Most graduate recruiters now looking for at least a 2:1. The Guardian. Retrieved from http://www.guardian.co.uk/money/2012/jul/04/graduate-recruiters-look-for-21-degree

Vick, R. M. (2011). How low-income, Ethnic Minority adolescents make Possible Selves real: The role of 
Academic Self-Regulation strategies (Bachelor's Thesis). Mount Holyoke College, South Hadley, Massachusetts.

Willie, S. S. (2003 ). Acting Black: College, Identity and the Performance of Race. New York: Routledge.

Yang, R. P., \& Noels, K. A. (in press). The possible selves of international students and their cross-cultural adjustment in Canada. International Journal of Psychology. http://dx.doi.org/10.1080/00207594.2012.660161

Yowell, C. M. (2002). Dreams of the future: The pursuit of education and career possible selves among ninth grade Latino youth. Applied Developmental Science, 6(2), 62-72. http://dx.doi.org/10.1207/S1532480XADS0602_2

\section{Note}

Note 1. In the UK Chinese students are considered to be a separate cohort to Asian students. Asian students in this context comprise UK students of Indian, Pakistani and Bangladeshi ethnic origin. 